\title{
O ORIENTALISMO NA TRADUÇÃO DA POESIA PERSA SUFI
}

\author{
Leandra Elena Yunis ${ }^{1}$ \\ -1Universidade de São Paulo, São Paulo, São Paulo, Brasil
}

\begin{abstract}
Resumo: O presente artigo trata da tradução da poesia persa em face da abordagem orientalista e seu contraponto ideológico islamista, que outorga à cultura islâmica uma essência oriental. Considerando a forte influência da religião zoroastriana na cultura persa e a sua sincretização na mística sufi, a autora problematiza as classificações místicas e religiosas atribuídas aos autores persas e apresenta uma tradução de trecho do Masnavi Ma'nawi de Jalal Uddin Rumi, poeta persa do século XIII, destacando a presença de elementos islâmicos e zoroastrianos em complementariedade. O trabalho também ressalta aspectos da historicidade a serem levados em consideração e pretende trazer uma contribuição original ao estudo e tradução de poéticas não ocidentais.
\end{abstract}

Palavras-chave: Tradução; Poesia Persa; Poesia Sufi; Zoroastrismo; Orientalismo

\section{ORIENTALISM IN TRANSLATION OF SUFI PERSIAN POETRY}

\begin{abstract}
This article deals with the translation of Persian poetry in face of orientalistic aproach and its ideological opposite, the islamism, which concerns a oriental essence to the Islamic culture. Considering the strong influence of Zoroastrian religion on Persian culture and its hybridism with Sufism, the author problematizes religious and mystical categorization of Persian authors and presents a translation of an excerpt from Masnavi of Jalal Uddin Rumi, XIIIth century Persian poet, highlighting the presence of Zoroastrian and Islamic elements in complementarity. This work makes evident some historicity aspects that
\end{abstract}


must be considered and intends to give an original contribution to the study and translation of non occidental poetics.

Keywords: Translation; Sufi Poetry; Persian Poetry; Zoroastrianism; Orientalism

Ao falar em poéticas não ocidentais, pode ser que alguns pensem ser real a divisão entre Oriente e Ocidente como uma linha que cruze o globo em duas partes, seja ela reta como o meridiano de Greenwich ou tortuosa como as fronteiras que recortam a antiga Terra Santa. Alguns de nós podem ainda supor a divisão noutro sentido, mais ou menos coincidente aos trópicos, pela qual se reparte o mundo entre a porção europeia e norte americana, incluindo Canadá, e outra terceiro mundista que englobaria os povos da África, da Ásia e da América Central e do Sul. Em tais divisões a determinação geográfica é quase sempre tão insatisfatória quanto a econômica e imprecisa do ponto de vista cultural e literário, já que literaturas como a de povos originários norte-americanos, por exemplo, poderiam ter mais em comum com a nossa literatura indígena do que com aquela em língua inglesa e, como notam especialistas, há notáveis paralelos entre os épicos persas e romanceiros medievais saxônicos. Nessa divisória conceitual, que é ideológica e sob diversos prismas controversa, há ainda o problema da representação histórica, marcada em grande parte por periodizações cronológicas estabelecidas para fins didáticos, tais como a idade antiga, medieval e moderna. Esse tipo de divisão, construída basicamente para abarcar processos econômicos e políticos relativos ao mundo europeu, é reducionista e não integra os processos civilizatórios de culturas "não ocidentais" que, nas mesmas épocas cronológicas, apresentam-se em diferentes processos que sequer são abarcáveis por critérios como do modo de produção. Então, por exemplo, enquanto no século XII em qualquer vilarejo europeu a maior parte das pessoas comuns não saberiam ler um bilhete em sua própria língua nativa ou no latim, em vastas porções dos territórios bizantinos e islâmicos a maioria dos citadinos era poliglota e mesmo os mais pobres tinham a possibilidade de frequentar 
escolas, além do que, qualquer um poderia adquirir com facilidade obras filosóficas, científicas, enciclopédicas ou artísticas numa feira de livros ao ar livre.

Por outro lado, a reconhecida superioridade cultural e científica de Bagdá em relação à Paris entre os séculos VIII e XII seria considerada mito alguns séculos depois, devido a franca decadência da sociedade islâmica a partir do século XIV e de seu antigos domínios a Leste e a Oeste, como Egito, Síria, Índia, etc, que passariam a ser retratados posteriormente nos relatos dos viajantes europeus do século XVII e XVIII como lugares de torpor, ignorância e retrogradação histórica apesar da exuberante beleza que ecoa um passado glorioso. Visto que uma das funções da História no início da época moderna era da Magistra Vitae, ou seja, ensinar com o exemplo do passado, os viajantes poderiam aferir de suas observações que a ambição humana leva às alturas tanto quanto aos abismos e tirar disto uma advertência sábia para o futuro da sua própria sociedade, em vias de comprometer-se com Iluminismo e progresso sem o cuidado de prever os perigos que tais ideais encerravam. Não obstante, de suas observações parece emanar apenas uma divisão binária entre sociedades históricas e a-históricas, critério artificial e ilusório pelo qual anulavam a historicidade alheia na descrição da realidade observada.

Preocupado com esse efeito ideológico dos relatos literários e, paralelamente, com a imprensa norte-americana e europeia que rotulava de terroristas jovens e crianças atirando pedras contra as tropas israelenses e tratores que destruíam as suas casas e famílias, Edward Said lembrou que aquele retrato do Oriente estático e retrógrado em face de um Ocidente desenvolvido e histórico era, tal como as notícias exageradas e falsas produzidas pelo lobbie sionista, um recorte intencional que visava reforçar a assimetria cultural e justificar a dominação imperialista. Uma vez que saber é poder, o autor britânico palestino ressaltou o papel ideológico da disciplina dos Estudos Orientais, constituída ao longo do século XIX sob o patrocínio de agências governamentais europeias com o claro propósito da dominação cultural. Como é 
sabido, o grande valor e peso da sua colaboração foi justamente este: a detecção do construto ideológico orientalista pelo qual se estabeleceu uma alteridade tão desigual na representação dos povos asiáticos e africanos pelos europeus.

Apesar de sua abordagem ter sido criticada e em boa medida superada em muitos sentidos, é irrefutável a sua constatação de que a disciplina orientalista, em geral aninhada nos departamentos de linguística, constitui um funil científico pelo qual o estudo de todas aquelas sociedades foi apartado dos demais e ganhou um lugar diminuto no campo do conhecimento. Por conseguinte, tais sociedades tiveram sua importância diminuída também na formação das pessoas; o que explica, por exemplo, a colossal lacuna que há em relação à História da Ásia e da África não somente nos currículos escolares mas em todas as universidades erigidas no modelo europeu. Mesmo hoje em dia, com todas as demandas por transversalidade e universalização do conhecimento, um estudioso com sólida formação em humanidades em qualquer reputada universidade pouco sabe sobre cultura e história dos impérios chineses, persas, africanos, árabes, mongóis, etc, ou mesmo das grandes civilizações ameríndias, a não ser que tenha ingressado em disciplinas optativas ou enveredado por pesquisas em áreas "exóticas". Acontece que essas áreas "exóticas" abarcam a mais extensa parte de toda a sociedade humana, tanto em termos geográfico quanto populacional e histórico, e é absurdo que nada ou tão pouco estudemos sobre elas oficialmente enquanto nos dedicamos a reis taumaturgos, classes estamentais, modos econômicos e outros fenômenos e modelos pouco ou apenas parcialmente úteis para a compreensão efetiva da história humana que, na realidade concreta, sempre esteve repleta de interações culturais e constantes deslocamentos populacionais dos quais o drama dos refugiados é somente o mais recente exemplo, tão expressivo e doloroso em todo o mundo.

A nossa formação é tão parcial e tão fragmentada que poucos de nós tem clareza, quando muito, de um tópico essencial da história geral como o cisma do império romano e o peso da política bizantina para a estrondosa expansão da religião muçulmana, na- 
queles tempos considerada uma seita herética que só posteriormente adquiriria autonomia e que hoje ameaça ser a mais numerosa (em termos de seguidores) do mundo. Diante de um cenário intelectual tão miserável, um pensador como Said, crítico e engajado (inclusive com a própria ancestralidade anglo-palestina) só poderia indignar-se, com razão, da facilidade com que seus colegas aceitaram como plausíveis as hipóteses aviltantes sobre a inexistência da Palestina histórica, absurdo reiterado até hoje contra todas as evidências científicas. ${ }^{1}$ Foi contra essa lógica "acadêmica” que o crítico literário buscou olhar não para as fronteiras que os homens estendem objetivamente no mundo concreto e sim para aquelas que erigem na mente e no imaginário e é a partir delas que pensarei a tradução no âmbito orientalista, algo que diz respeito diretamente à poesia com a qual lido.

Para Said, o conhecimento sobre o Oriente:

é adquirido tão literal e tão amplamente quanto possível pelo Ocidente que o domestica filtrando-o através de códigos reguladores, classificações, espécimes, revistas, dicionários, gramáticas, comentários, edições, traduções, todos os quais formam um simulacro do Oriente (SAID, 232).

a ser reproduzido materialmente para o Ocidente. Nesse sentido a tradução é somente um recurso e, ao mesmo tempo, o mais importante deles, já que quase tudo que será reproduzido passa por ela. Daí que o autor sublinhe o papel do "turjaman (do árabe) [que] significa 'intérprete', 'intermediário' ou 'porta-voz”" (Said 232). Por esse motivo também, a projeção orientalista é mais nítida nas traduções, uma vez que elas constituem a fina camada que retrata a fronteira imaginária e onde se estabelece a peneira pela qual o

\footnotetext{
${ }^{1}$ A historiadora Arlene Clemesha faz notar que a retirada do conteúdo relativo ao tema dos materiais didáticos produzidos no Estado de Israel é nitidamente ideológico e sem fundamento cientifico (2005).
}

Cad. Trad., Florianópolis, v. 39, nº esp., p. 78-100, set-dez, 2019 
Oriente figurará como tal. Isso diz respeito não apenas ao modo como a tradução é feita em termos técnicos, isto é, transposição de marcas, recursos e estilos que afetam substancialmente o sentido e o caráter do que é produzido, mas sobretudo ao filtro ideológico que precede a investigação conceitual implicada nas escolhas semânticas e na reconfiguração de um discurso em tradução.

Isso é especialmente válido para a tradução da poesia persa sufi, pois além do filtro orientalista há outro que precede toda a abordagem da mística islâmica. Nas traduções dos tratados sufis, por exemplo, há abundantes transliterações que parecem produzir uma estrangeirização aparentemente contrária à domesticação linguística, um mecanismo tipicamente orientalista de assimilação auto projetiva. Entretanto, esse procedimento revela justamente o problema espinhoso da transposição conceitual: no caso dos termos herméticos sufis, descobrimos serem os vocabulários místicos formados por empréstimos linguísticos que requerem longos parágrafos explicativos ou por traduções veladas e tergiversadas de léxicos filosóficos e místicos derivados de outras tradições culturais. O que os orientalistas fazem (aos menos os britânicos) é deixar o problema prudentemente irresolvido. Com isso, entretanto, se estabelece uma mistificação dos termos que sobrevive como um modus operandi do orientalismo acadêmico que se estende ao pseudo-academicismo de engajamento místico.

Como em geral o sufismo costuma interessar somente aos místicos, aqueles que se engajam no seu estudo com frequência desconsideram a historicidade conceitual da mesma forma que ignoram o artifício do gênero hagiográfico destinado propositalmente a estabelecer o perfil sobrenatural dos santos retratados para validar crenças. Além disso, com frequência adota-se a historiografia religiosa islâmica de modo unilateral e à qual as hagiografias estão conexas por uma lógica circular e simbólica, que Henry Corbin (25-37) chamou de hierohistórica: isto é, cada fenômeno serve para reiterar o sentido da revelação divina e não o sentido da escolha, da criatividade ou da liberdade humanas. $\mathrm{O}$ problema maior é que a abordagem crítica dessas fontes se com- 
plica em função de tal circularidade simbólica encontrar-se na própria narrativa historiográfica, mesmo em autores de avançada consciência teórica, como Ibn Khaldun.

Uma vez que, como sugere Senko (41), a narrativa dos fenômenos relativos a cada sociedade sob dominação islâmica esteve sujeita à uma estrutura morfológica que mesclava mito e realidade na superposição dos registros genealógicos, biográficos e cronísticos e que, buscando acompanhar a lógica interna dos historiadores muçulmanos, os orientalistas apenas transpuseram a cronologia das eras dinásticas a circularidade hierohistórica permaneceu subjacente na sua modulação temporal ocultando as perspectivas culturais diversas e em conflito com a religião dominante. Essa conduta epistemológica determinou escolhas semânticas importantes na tradução de materiais, incluindo literários, que era realizada muitas vezes pelos próprios pesquisadores. No caso da tradução da poesia de Jalal Uddin Rumi, místico persa do século XIII, por exemplo, verifiquei em minha pesquisa que o termo raqs (do árabe, "dança") foi traduzido por Reynold Alleyne Nicholson com base num tratado do século XVII, do teólogo Ankaravi, que definiu o rito coreográfico Mevlevi como samá (do árabe, "audição") para evitar a censura que recaía então sobre a prática coreográfica. Porém, Rumi utilizara o termo "dança" no século XIII num sentido teológico intencionalmente distinto do de "audição" e muito sofisticado, além de praticar uma dança mística num formato espontâneo e livre muito diferente daquele do rito estabelecido pos mortem em sua homenagem e que no século XVII já apresentava mudanças substanciais. O fato do mestre místico ter dialogado em sua obra com outros autores sobre a liberdade artística já estava completamente fora do horizonte e do interesse dos místicos e religiosos para os quais o sufismo se tornava a cada dia menos sincrético e mais dogmático.

$\mathrm{O}$ procedimento anacrônico, de tomar o sentido de um termo por um conceito definido em fonte de época muito posterior, che-

\footnotetext{
${ }^{2}$ Conhecida também como a Ordem do Dervixes Rodopiantes, fundada no século XIII por Rumi em Konya, atual Turquia.
} 
gando a concebê-lo no sentido oposto ao do original, algo grave num autor que traduziu outras fontes do debate sobre a dança e a audição, pode ser considerado uma atitude tipicamente orientalista, que reputa a imobilidade histórica aos povos dominados. Isso é especialmente comum no caso da mística, em que se supõe que o desinteresse pelos assuntos mundanos - reiterado pela máxima de que "o sufi está no mundo sem pertencer a ele" - resulta na sua automática imunidade à mudanças históricas. Contudo, Nicholson pode ter considerado natural que os significados das palavras e dos termos na tradição sufi fossem imutáveis porque, como a maioria dos seus colegas, ainda estava ocupado na tarefa de desvendar os contextos através da sua própria tradução de fontes e obras historiográficas de época que eram, em si mesmas, marcadas por aquela circularidade hierohistórica. Portanto, sua leitura foi enredada pelo filtro islâmico antes mesmo de o ser pelo orientalista.

Outro caso interessante é o das traduções de Omar Khayyam, autor persa do século XI, cujas versões livres de Edward Fitzgerald tiveram um enorme impacto sobre a sociedade literária europeia do século XIX. Fitzgerald traduziu os rubais de Khayyam na forma aproximada das quadras e ressalta-lhes o tom cético puramente hedonista, estabelecendo uma identificação ideal com o espírito europeu moderno. Jean Baptiste Nicolas, o tradutor francês, fará o contrário e atribuirá uma faceta mística ao astrônomo do Irã. Khayyam se tornou rapidamente um dos poetas persas mais traduzidos e retraduzidos do inglês e do árabe e essa duplicidade na apresentação do caráter do poeta, se filósofo cético ou místico, se tornou muito polêmica. Entre os iranianos, o escritor e crítico modernista Sadegh Hedayat irá exultar com a tradução de Fitzgerald, que baseou-se em poemas considerados autênticos, e criticar com veemência a seleção de Nicolas, cuja autenticidade é difícil de rastrear ou validar. Apesar dos argumentos bastante pertinentes e prováveis de Hedayat, nunca saberemos se Khayyam era como ele diz, dos poetas persas "o mais franco a negar Deus e fazer estremecer os fundamentos dos mitos religiosos" (Omar Jayyam 35) ou se, mais comedidamente e ainda assim brilhante, o poeta da 
perplexidade. Além disso, nada impede que Khayyam tenha tido uma fase de experimentação poética da temática mística, renegada com fervor por Hedayat, engajado por sua vez na modernização do Irã e na eliminação do legado islâmico que no início do século XX já se apresentava devastador e opressivo. Nesse caso vemos que na fina camada da tradução não há somente a projeção orientalista ou islâmica a estabelecer a fronteira imaginária das supraculturas.

Se o caráter hierohistórico da historiografia islâmica demonstra que a dominação árabe foi tão problemática em termos ideológicos quanto a dominação europeia, a conversão de autores céticos ou ateus em místicos declarados, como se deu em relação a Khayyam e, talvez, Hafiz, um agudo crítico dos sufis de seu tempo, pode sinalizar o anseio moderno de reforçar a obliteração da diversidade cultural e religiosa no mundo islamizado que antes de serem apagadas pela caneta europeia já haviam sido dissolvidas historicamente no cálamo muçulmano. Nesse caso, temos, segundo Husain (117) uma revalidação da ideologia islâmica reforçada pelo islamismo moderno, cuja orientação mais radical reconhecemos na expressão de grupos extremistas como Isis/Daesh e Al Qaeda, ou de governos islâmicos radicalmente ortodoxos, como os da Arabia Saudita, e de movimentos ou partidos favoráveis ao retorno do califado, como o Hezbollah, ou na teocracia dos aiatolás xiitas, já pressentida por Hedayat. Said identifica no islamismo o "desaparecimento gradual da extraordinária tradição do ijtihad (debate) islâmico” (24) o que ele considera

um dos maiores desastres do nosso tempo, com o resultado de que o pensamento crítico e os embates individuais diante dos problemas do mundo simplesmente saíram do cenário. Em vez disso, imperam a ortodoxia e o dogma" (24)

que impedem igualmente uma alteridade horizontal, justa e pacífica.

Todos esses "filtros" ideológicos que dividem a mesma fronteira do binômio Oriente/Ocidente pressupõe, conforme Meschonnic 
(20-21) diferentes tipos de historicidade/alteridade na tradução da poesia persa sufi: enquanto a abordagem orientalista estabelece uma historicidade assimétrica, na qual se subentende que o sufi é a-histórico, a perspectiva islâmica assimila tudo à sua circularidade hierohistórica. Posteriormente, o islamismo reforça o anulamento temporal hierohistórico ao exagerar a "islamicidade" de uma obra sufi (ou objeto de estudo) em tradução e ocultar os traços de pressupostos não islâmicos ou até mesmo anti-islâmicos. Podemos dizer que há ainda uma outra tendência ideológica, representada por Hedayat, que é a de um anti-islamismo de resistência e que, nesse caso, reforça a identidade persa independente da fronteira orientalista, conforme discutirei adiante. Por isso a historicidade na tradução de obra remota não pode ser pensada separadamente da ressignificação histórica, nos termos de Dilthey, pois cada uma dessas tendências ideológicas estabelece um dos nexos que liga o passado ao presente através da obra traduzida ou reeditada e das versões/épocas entre si.

Em tese, o islamismo parece opor-se ao sufismo como doutrina, pois os seus sujeitos históricos atuam em direções opostas e são divergentes com relação ao modo de vida e a realização da paz (islã) no mundo. Entretanto, o seu efeito dogmático se faz sentir na tradução da poesia persa quando se perde a perspectiva dinâmica do desenvolvimento histórico da mística, que só pode ser evidenciada numa abordagem crítica do sufismo, o que é especialmente valioso para a tradução e estudo da poesia persa clássica, pois a linguagem mística é tida como marca distintiva da forma clássica. Isso não invalida de modo algum o valor do sufismo em termos de proposta estética e de apreensão da realidade, original na sua forma específica de sintetizar tradições, nem o seu peso simbólico na dimensão semiótica da apreensão poética, seja de uma obra sufi, seja de uma obra que adquire posteriormente esse uso.

O problema fundamental do efeito hierohistórico reforçado pelo islamismo nos estudos sufis é que ele oblitera ou diminui o peso das referências zoroastrianas na tradição literária persa, apesar destas serem abundantes e de uso corrente. Assim, quando 
Rumi se dirige ao Sol ou mesmo ao mestre Shams (nome que em árabe significa "sol") está aludindo de forma polissêmica a Ahura Mazda, o Deus zoroastriano cuja hierofania sagrada é o sol, signo que certamente não é conferido a Allah pelo profeta Maomé. Aliás, mesmo quando o poeta se refere a Deus no seu monumental comentário teológico, o Masnavi Ma'nawi (Dísticos Espirituais), salvo no caso das citações corânicas, ele usa o termo persa khud e não raro aplica o vocábulo yazdani, relativo às divindades zoroastrianas que emanam de Deus nas formas naturais da água, do céu, da terra, dos animais etc. Isso tudo sugere uma sensível permanência de elementos zoroastrianos no interior de uma cultura mística bastante sincrética e que bem poderia ser uma forma camuflada da própria espiritualidade persa acomodada no seio de uma sociedade fortemente regulada pela religião dominante estrangeira. Além do mais, o poeta viveu a maior parte da sua vida numa cidade bizantina recém conquistada por muçulmanos turcos e repleta de gregos e armênios com os quais desenvolveu estreitas relações, o que nos leva a questionar, a propósito da questão orientalista/islamista, se: 1) ele deve ser considerado um poeta "oriental"?; 2) a cultura persa poderia ser considerada “oriental”?; e, por conseguinte, 3) o sufismo é ou em que medida pode ser considerado um fenômeno "oriental"?

Os estudos persas e as traduções da obra de Rumi ou de outros poetas, bem como dos tratados científicos, teologais etc, de origem e em língua persa, se deram no interior do projeto acadêmico orientalista por serem assuntos ligados àquela porção do território asiático que, embora independente, estava sob o protetorado britânico desde o início do século XIX. Porém, o que é “oriental” para o orientalista não é o mesmo que para o islamista. Este último invoca a própria orientalidade baseando-se na noção de que o islã emergiu em oposição à barbárie pagã tanto em Meca quanto no Ocidente, onde culturas como a franca e a saxônica deturpavam a missão sagrada professada nas Escrituras. De modo que a revelação de Maomé aos árabes e por eles estendidas aos demais povos garantiria, de certa forma, a preservação do modo de vida semítico original em contra- 
posição ao romano ocidental. O que é islâmico seria então, nesse sentido, oriental, isto é, anti ocidental ou, ao menos, não ocidental.

A questão é que a cultura persa nativa não é originalmente semítica nem islâmica, mas indo-ariana e zoroastriana. A origem do zoroastrismo remonta a pelo menos 12 séculos antes da hégira e constitui uma forma proto-monoteísta intuitiva e emanacionista, no sentido de que concebe toda manifestação natural como emanação divina como entendida por Du Breuil. A sua principal diferença com relação a tradição islâmica é a ênfase na visualidade como meio de testemunhar a verdade, pois a luz enquanto atributo divino é que permite desvendar o aparente e dissipar o oculto. A forma pura da luz é o pensamento pelo qual o homem pode desvendar por si mesmo os sinais externos e os valores internos e a intuição é a linguagem divina pela qual Deus fala diretamente a cada um em sua consciência. No islã, pelo contrário, se estabeleceu uma religiosidade ligada à oralidade em que a verdade é acessível ao coração humano por meio da audição e da aceitação da palavra recebida durante a recitação corânica.

Tratam-se, portanto, de duas perspectivas completamente opostas e divergentes, pois enquanto o zoroastrismo prega a autonomia de pensamento e a relação intuitiva com Deus, o islã prega a submissão ao invisível, o que é entendido na prática como submissão à autoridade recitativa. Enquanto a tradição islâmica está centrada na oralidade, o zoroastrismo está calcado na visualidade e não dispensa a sensorialidade de um modo geral, que acessa as manifestações naturais divinas. Portanto, se a oralidade é a marca do oriental, a visualidade é o seu oposto e situa o zoroastrismo fora da espiritualidade "oriental". Ademais, a cultura persa é tributária da metafísica grega desde ao menos o século VI a.C. (Iqbal), o que anula a sua classificação como oriental sob o postulado de Heródoto, ao defini-los como povos bárbaros. Por fim, a recuperação do legado zoroastriano durante a modernização do Irã na era Páhlavi significou para os xiitas uma hostil investida no sentido da ocidentalização, o que impossibilita definitivamente uma classificação oriental/ocidental da tradição persa, mesmo que meramente instrumental. 
Quanto ao sufismo, caso fosse uma mística puramente calcada na audição poderíamos considerá-lo um fenômeno oriental segundo a acepção estritamente islâmica; contudo, sabemos que desde os primórdios o desenvolvimento dessa tradição envolveu um movimento intelectual e filosófico considerável e um processo de sincretização cultural inquestionável. Uma das suas linhas doutrinárias principais, a via do amor (ou da paixão), teve forte enraizamento na tradição zoroastriana e se institucionalizou justamente durante os séculos em que o sunismo, e não o xiismo, era predominante na região de cultura persa. ${ }^{3}$ Portanto, como a tradição sufi persa não é essencialmente oriental nem puramente islâmica, o que resta é distinguir até que ponto as traduções da poesia persa clássica, produzida entre os século X e XIV e portanto antes da dominação xiita, podem acessar o legado zoroastriano enquanto permanência cultural ou convergir perigosamente para uma reiteração da tradição islâmica.

Uma das formas de balizar essa pendular oscilação no processo tradutório da poesia persa talvez seja mantendo a atenção na dinâmica das historicidades envolvidas nos diferentes processos tradutórios e, sobretudo, na consciência de que a tradução restaura um elo de ressignificação histórica da obra que pode ocultar ainda mais os sentidos históricos latentes ou trazê-los à luz. Esse elo será mais fortalecido na medida em que o tradutor não sucumba à ilusão de seguir fielmente uma pretensa tradição “original”, já que ele já está de fora do tempo histórico da obra e não pode mais acessá-la desse modo. O que ele pode é conhecer um contexto histórico reconstituído por meio de historiografia especializada e de documentos de época que, mesmo assim, devem ser analisados criticamente e em contraste com outros produzidos sob abordagens diversas.

Em termos propriamente estéticos, para dotar as imagens e conceitos persas de um valor que seja ao mesmo tempo contextual, no

${ }^{3} \mathrm{O}$ xiismo se tornaria oficial naquele território somente a partir do século XVII e por imposição do xá safávida Ismail, enquanto o zoroastrismo permaneceria como uma minoria religiosa tolerada ao lado das demais minorias sunitas, também hibridizadas a diversas formas de espiritualidade masdeístas. 
sentido de fidedigno, e histórico, no sentido da sua revalidação histórica para o presente, é preciso que o tradutor tente ao menos ver no sentido zoroastriano e ouvir no sentido islâmico. Além disso, como a poética persa está inserida numa dinâmica inter-estética e sincrética, seja ela sufi ou profana, é preciso também detectar sinergicamente a estrutura arquetípica pela qual o receptor/ouvinte interage com o campo da significação poética de forma intuitiva e lúdica, interativa e dinâmica. Essa estrutura não está na forma poética em si, que segue uma convenção retórica, mas pode ser decifrada a partir do symbolon que, segundo Meisami (323) organiza as imagens metafóricas numa manifestação imaginária que resulta da combinação dos recursos silogístico, afetivo e sensorial. Vejamos um exemplo:

Figura 1: Masnavi Ma’nawi III: 3901-3905

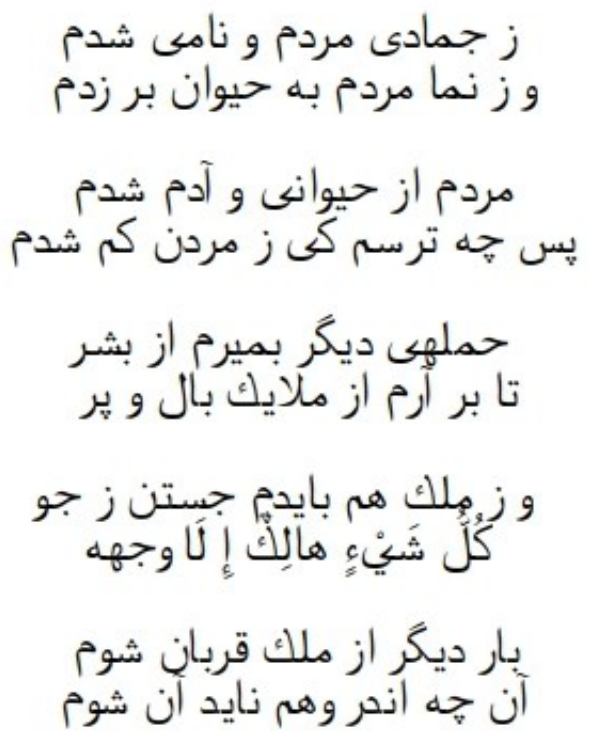

Fonte: 3901-3905 (Rumi, 1207-1273; edição bilíngue de Nicholson, 1940) 
Tradução literal

Como mineral morri e crescente [vegetal] me tornei.

E da erva morri, ao animal cheguei.

Morri como animal e Adão me tornei.

$\mathrm{O}$ quê devo temer se ao morrer menos não me tornarei?

Repentinamente outra vez a morte me leva do humano, até que me cubram do anjo as asas e as penas.

E conforme atinja os anjos, expandirei/saltarei da partícula, [pois] tudo se esvai menos o seu rosto.

Rebrotarei de novo do anjo sacrificado

lá/naquele, onde quanto mais se entra menos se chega.

\section{Samatradução ${ }^{4}$}

\section{Morri mineral}

Morri mineral, na flor renasci.

De erva perecida, animal revivi.

De animal abatido cheguei a Adão.

Temerei a morte se não há extinção?

Do humano a morte me leva de súbito

até que as penas em asas me cubram

e da partícula do anjo me esparse

[pois] tudo se esvai exceto a Sua face.

Acima dos anjos irei rebrotar

dentro do inatingível, dissipar

\footnotetext{
${ }^{4}$ Neologismo baseado no termo aŕabe "samá" (audição) que uso para indicar uma metodologia criada por mim para a recriação poética da poesia persa sufi que pretendia combinar a gnose intuitiva, a abordagem histórica e a interação lúdica com o campo imaginário e semântico do poema .
} 
Este é um dos poemas mais conhecidos da poesia de Rumi e foi apresentado no Brasil como "A evolução da forma” por José Jorge de Carvalho (66) em retradução a partir de outros idiomas. Tratase de um breve trecho dos Dísticos Espirituais (nome dado ao Masnavi Manawi em português) em que o poeta cita alusivamente o corão no verso “Tudo perecerá exceto Seu rosto". A temática mística é a da mutação de estados do espírito em sua passagem pelo plano material até a extinção (faná) na união com Deus e verificamos que o poeta compreende tal processo como constante morte e renascimento de uma mesma essência que conhece diversas naturezas na existência. As formas sucessivas do seu existir não são aleatórias, mas representam justamente etapas de evolução da alma espiritual nos diferentes estágios da natureza: mineral, vegetal, animal, humana e angelical. A última etapa consiste num reino superior no qual, literalmente, "quanto mais se entra, menos se chega", isto é, o campo da dissolução absoluta. Essa noção de uma experiência espiritual circular que experimenta a matéria através da alma e retorna ao plano divino tem eco na tradição plotiniana, conhecida pelos sufis por meio de traduções árabes do Pseudo-Aristóteles e segundo a qual a experiência mundana é incorporada ao plano celestial como aprendizagem.

O que chama a atenção no trecho, contudo, é que o foco do processo recai na transmutação mais do que na aprendizagem. Pode-se inferir também que o ser em mutação referido na $1^{\mathrm{a}}$. pessoa do singular seja distinto daquele cujo rosto se mantém, isto é, o Deus corânico, embora se comporte como uma entidade espiritual perene abrangente e não particularizada. Todos as manifestações se apresentam como condições momentâneas dessa mesma essência e, nesse sentido, são concebidas também como almas coletivas em manifestação naturais, incluindo a dos anjos, uma vez que naquela cosmologia medieval os seres mágicos, gênios e anjos tem uma natureza preternatural, isto é, contígua ao universo sensível. Essa noção de alma manifesta em natureza se aproximam à concepção zoroastriana dos yazdanat, seres sagrados naturais imortais emanados da divindade como atributos 
de poder direto e efetivo. Rumi parece evidenciar essa noção para matizar ou mesmo subverter o princípio religioso aludido na citação, pois o tom severo do castigo corânico a respeito do Juízo final é aqui suplantado pela noção de crescimento espiritual por meio da transmutação e da aproximação da natureza divina através da natureza mundana. Podemos supor inclusive que a primeira pessoa do singular é voz da própria divindade que (ao modo zoroastriano) fala através do poeta, cujo papel de profeta seria algo bem mais natural do que especial, o que corrobora a noção filosófica da revelação como princípio intuitivo universal de acesso humano aos desígnios divinos.

Independente desta interpretação, é importante identificarmos no texto original a estrutura arquetípica do poema. Trata-se de um trecho de masnavi, portanto de uma reflexão exposta em dísticos rimados que variam do decassílabo ao dodecassílabo, uma forma simples e adequada para verter provérbios e temas coloquiais em estrutura de fácil memorização. Portanto, não é precisamente na forma que se situa a estrutura simbólica, mas na articulação desta com a imagens construídas por meio do uso silogístico de verbos e substantivos que, dispostos escalonadamente a cada dístico, indicam os estados sucessivos de manifestação do ser em quadros cujas imagens inicialmente densas se tornam difusas devido ao movimento contínuo da mutação que se exprime como ascensão, evolução e expansão/difusão até a extinção. Trata-se do arquétipo sufi da morte, desenhado enquanto transmutação permanente do "eu" lírico com o qual o leitor/ouvinte deverá também se identificar e esvair-se por dentro. Nessa noção do imutável que persevera dentro da mutabilidade existe algo da lógica do tao, por figurar como uma espécie de energia neutra e mediana que atravessa a impermanência e a transitoriedade, daí que a estrutura do símbolo ou arquétipo imaginário do poema seja ela própria meta simbólica, no sentido de estabelecer uma imagem que se desfaz ao invés de fixar-se numa forma estável.

Embora o dístico seja uma estrutura previsível, neste caso a tradução deve ser especialmente cuidadosa com a citação parcial do 
versículo corânico, pois a sua transposição determinará a fórmula oral da recitação poética e deve ser identificável aos muçulmanos, logo, a sua reformulação depende das traduções do sentido do Corão disponíveis na língua portuguesa ${ }^{5}$. Mesmo não tendo conhecimento da língua árabe, comentarei a minha escolha semântica para a citação alusiva que Rumi faz do versículo 28:88 do Corão, que foi orientada pelo próprio texto poético e por uma espécie de intuição baseada na ideia disseminada entre os sufis de que o Masnavi Ma'nawi seria "o Corão em persa” e, portanto, uma espécie de tradução. Seguindo a lógica persa e considerando o que foi analisado anteriormente, o trecho poético me pareceu mais ressonante com a ideia apresentada na versão de Samir al Hayek (1974), onde lê-se o versículo inteiro da seguinte forma: "E não invoqueis, à semelhança de Deus, outra divindade, porque não há mais divindades além d'Ele! Tudo perecerá, exceto o Seu Rosto. Seu é o Juízo, e a Ele retornareis!”.

Para o mesmo trecho, eu tinha à mão uma outra tradução substancialmente diferente, aquela realizada pelo professor Helmi Nasr (641), onde se lê: "E não invoqueis, com Allah, outro deus. Não existe deus senão ele. Todas as cousas serão aniquiladas, exceto sua Face. DEle é o julgamento, e a ele retornareis”. A diferença entre ambas não é meramente linguística, pois no que se refere à idolatria, condenada no capítulo em questão, a tradução de Hayek enfatiza a ação mimética de tomar outra divindade à semelhança de Deus, enquanto Nasr sugere uma substituição direta. Além disso, o primeiro traduz o termo "Allah" ao português, isto é, "Deus", enquanto o segundo mantém o estrangeirismo; ademais há uma diferença substancial entre "tudo perecerá" e "todas as cousas serão aniquiladas", já que no primeiro caso se presume a morte como resultado da corrupção natural, enquanto o uso da voz passiva, do substantivo "cousas" e do verbo "aniquilar" denotam a destruição proposital do que parece ser meramente material; por fim, há a divergência terminológica entre "face" e "rosto".

5 Parecem totalizar em 11 até o presente momento, das quais quatro foram publicadas no Brasil e citamos apenas as consultadas.

Cad. Trad., Florianópolis, v. 39, n $^{0}$ esp., p. 78-100, set-dez, 2019 
Ainda que não haja diferença semântica entre "face" e "rosto", o primeiro vocábulo presume também a expressão (facial) como gesto e não apenas a materialidade mesma da parte superior da cabeça. Essa é a solução oferecida pelo professor Nasr, mas seria um erro extremamente grave adotar integralmente a sua tradução para amparar a nossa tradução do versículo citado em Rumi, sobretudo pelas suas marcas ideológicas e linguísticas. Além da arabização do nome de Deus, que desvincula a tradição corânica do cristianismo e do judaísmo, as duas principais correntes monoteístas das quais se desenvolveu historicamente, não se pode ignorar o fato de que a tradução de Nasr, distribuída gratuitamente e circulando amplamente no país, foi publicada na Arabia Saudita e sob o patrocínio do rei Fahd, em 2005. Com é sabido, a casa saudita segue a doutrina wahabita que propõe uma interpretação literal do Corão num sentido muito estrito e radicalmente oposto ao que pregam as demais correntes islâmica tradicionais. O literalismo se opõe ao modo exegético sufi de interpretar e, em especial, ao de Rumi que, enquanto teólogo, se insere na tradição hanafita, caracterizada justamente por usar analogias e compreender imagens tais como a "face de Deus" de modo metafórico e não literal. Mais do que isso, o wahabismo é tributário do hanbalismo, a mais ortodoxa das linhas de jurisprudência islâmica e justamente aquela que promoveu a censura às artes e à prática mística ao longo séculos, cujos pressupostos reducionistas e dogmáticos ainda hoje são retomados pelos wahabitas para fundamentar severas leis e punições. Portanto, usar a sua tradução nesse caso seria de uma grande limitação, incongruência e afronta ao livre pensamento do poeta.

Para superar a insegurança de lidar com duas traduções tão distintas num idioma desconhecido, recorri a uma terceira versão em edição recente, a tradução de Mansour Chalita, publicada no Brasil em 2015, patrocinada pela Liga Árabe e respaldada pelas autoridades recitativas tradicionais, que apresenta a seguinte solução: "E não invoqueis deus algum com Deus. Não há deus senão Ele. Tudo está destinado a perecer exceto a sua face. A Ele pertence o julgamento. E para ele voltareis". Neste caso, enfatiza-se que a invocação a Deus não deve supor nenhuma divindade intermediária 
ou adicional, reforçando-se a unicidade de Deus em face da impotência real das demais manifestações consideradas divinas. Por fim, antes de pender por esta última, recorri ao auxílio de um nativo especialista no tema, tanto na tradução de poesia quanto na tradução corânica, Michel Sleiman, quem elucidou que o verbo árabe "halek" estaria melhor vertido por "perecer" do que "ser aniquilado", já que denota a exaustão ou perda do valor, da vitalidade e da potência intrínseca às coisas, seres e ideias na condição transitória da existência mundana. Trata-se do perecimento não somente do que é material mas também do que é imaterial e já terá se desfeito no tempo do Juízo final, cujo destino de salvação ou danação (não necessariamente extinção) das almas se decidirá. Portanto, a reflexão abrange as diversas noções humanas de divindade, igualmente frágeis e falíveis, tais como (penso eu) a própria "imagem" que cada um faz de Deus, sujeita a extinguir-se diante da Sua verdade inatingível, como sublinhou Rumi. Pois o poeta sugere que a própria face divina é o ponto derradeiro, ambiente de integração/ desintegração definido no sentido absolutamente apofático do impermeável, intangível, inacessível, onde "mais se entra, menos se chega" - expressão coloquial que, embora compreensível, não flui no português e por isso vertida aqui como "inatingível". De um modo geral, podemos constatar que a "tradução" que Rumi faz por meio do comentário alusivo culmina, em termos tradutórios, com o ajustamento dessa refinada noção teológica à perspectiva zoroastriana, que vê na divindade primordial a fonte de toda existência por ser em si mesma a pura e eterna sabedoria, consciência e verdade.

Quanto ao ritmo, descobrimos que é em função do versículo em árabe kulu cha'in haalikun illaa wajhahu que devemos ler o hemistíquio persa do seguinte modo: $\boldsymbol{w}$ zu malek ham bâyadam jestan az dju (ao invés de wa ze malek ham bâyadam jestan ze djo), ${ }^{6}$ com rima final e inicial tonantes, padrão no masnavi persa, o que ressalta o paralelismo entre jestan az dju (escapar ou saltar da partícula;

${ }^{6}$ Considerando que as regras de transliteração diferem entre persa e árabe para os mesmos grafemas, apresento-as por aproximação sonora em português.

Cad. Trad., Florianópolis, v. 39, $\mathbf{n}^{0}$ esp., p. 78-100, set-dez, 2019 
sair em busca, descobrir, encontrar no ar/atmosfera) e wajhahu (a face Dele), cuja preservação da polissemia dentro do padrão formal só pode ser captado inteiramente no original e para a qual encontrei por solução humanizar o verbo "esparsar", exatamente ao modo persa de formar verbos a partir de qualquer elemento gramatical, ação, substantivo, adjetivo etc, e que é possível com a simples conjugação do tema radical (isto é, a raiz da palavra).

Mesmo sem conhecimento direto da língua árabe pude ponderar sobre o sentido do verso citado por Rumi com base em considerações históricas e numa leitura sincrônica do texto. Porém, em casos como este, em que há citação religiosa e o comentário poético é considerado pela própria tradição mística como uma tradução, torna-se imprescindível refletir sobre as traduções e interpretações em torno do livro sagrado buscando não apenas o seu "nobre sentido", estipulado sabe-se lá por quais tendências, mas a contextualização histórica e crítica da sua dimensão semântica, bem como o estudo do constructo poético e da cantilena do verso em sua estrutura formal. Nesse último aspecto, destaca-se a tentativa de Nagib Modad, em 1961, de transpor os versículos corânicos em decassílabos rimados, afastando-se, contudo, da emulação prosódica e do ritmo original, tarefa que tem sido realizada de forma cuidadosa e apenas esparsamente publicada (de forma extraordinariamente modesta para a sua grandeza) pelo professor Michel Sleiman, a quem dedico o presente artigo. Mesmo no Brasil, onde há um número menor de interessados na literatura persa do que na mística sufi, a abordagem crítica do Corão é tão crucial quanto uma tradução direta ao português (ainda inexistente) do Avesta, o livro sagrado zoroastriano. Enquanto isso, graças ao filtro islamista nos estudos sufis, o Oriente ainda figura como o "interior", o campo da introspecção e do significado, enquanto o Ocidente se apresenta como o "exterior", o campo da forma perecível, até que finalizemos a missão deixada por Said, "talvez a mais importante de todas que é a de empreender estudos das alternativas contemporâneas do orientalismo e perguntar como é possível estudar outras culturas e povos a partir de uma perspectiva libertária ou não repressiva e manipuladora" (Said 55). 


\section{Referências}

Du Breuil, Paul. Zoroastrisme. Paris: Presses Universitaires de France, 1982.

Chalita, Mansour. O Corão - Livro Sagrado do Islã. Rio de Janeiro: Editora Record/Bestbolso, 2015 (1980).

Clemesha, Arlene. "Uma educação para preservar a identidade". Revista Entre Livros - Para entender o mundo árabe, ano I n. 3. São Paulo: Duetto, p. 36-41, 2005.

Dilthley, Wilhelm. El mundo histórico. México: Fóndo de Cultura Económica, 1944.

Hayek, Samir. O Significado dos Versículos do Corão Sagrado. São Paulo: Editora Marsam, 1974.

Husein, Ed. The house of islam. A global History. London: Bloomsbury, 2018.

Iqbal, Muhammad. The development of the metaphyisics in Persia. A contribution to the History of the Muslim Philosophy. London: Luzac \& Co, 1908.

Lory, Pierre; Viellard-Baron Jean-Louis. "Temps spirituel et hiéro-histoire selon Henry Corbin: une phénoménologie de la conscience psycho-cosmique". In: Archè Milan (Ed.). Henry Corbin et le comparatisme spirituel. p. 25-37, 2000.

Meisami, Julie. Structure and Meaning in Medieval Arabic and Persian Lyric Poetry - Orient Pearls. London: Routledge, 2003.

Modad, Nagib. O Corão Sublime - versão do sentido em português. Belo Horizonte: Editora Evoluir, 1961.

Nasr, Helmi, Tradução do Sentido do Nobre Corão. Madinah (Arábia Saudita): Complexo de Impressão do Rei Fahd, 2005 (1426 A.H.). 
Omar Jayyam. Robaiyyat, Taraneh haye Khayyam. Tradução Zara Behnam e versão espanhola de Jesús Munárriz. Texto bilíngue. Madri: Ediciones Hipérion, 2010.

Rumi, Jallal Uddin. The Mathnavi of Jalaluddin Rumi. Versão bilingue persa/ inglês de Reynold Alleyne Nicholson. London: Luzac, 1940.

Rumi, Jallal Uddin. Poemas místicos. Divan de Shams de Tabriz. Tradução José Jorge de Carvalho. São Paulo: Attar, 1996.

Said, Edward W. Orientalismo. O Oriente como invenção do Ocidente. Tradução Rosaura Eichenberg. São Paulo: Cia das Letras, 2007.

Senko, E. C. "Perspectivas e sintomas da historiografia do período tardo medieval: um encontro entre Ocidente e Oriente." In: Revista Vernáculo, n. 25 Paraná: UFPR, p. 28-42, 2010.

Meschonnic, Henri. Poética do traduzir, não tradutologia. Três traduções interlinguais por Márcio Weber de Faria (espanhol), Levi F. Araújo (inglês), Eduardo Domingues (português), Belo Horizonte FALE / UFMG, 2009.

Yunis, Leandra E. Samatradução: a dança num exercício de tradução do gazal de Rumi. Tese de Doutorado. Universidade de São Paulo, 2017.

Recebido em: 15/10/2019

Aceito em: 30/11/2019

Publicado em dezembro de 2019

Leandra Elena Yunis. E-mail: leyunis@gmail.com

ORCID: https://orcid.org/0000-0002-1142-1973

Pesquisa realizada com auxílio Capes-DS concluída em 2017. 